\title{
BROOMRAPE THREAT TO AGRICULTURE
}

\author{
Diego Rubiales, Institute for Sustainable Agriculture, CSIC, I4004 Córdoba, Spain
}

Key words: Orobanche, Phelipanche, management, parasitic weeds

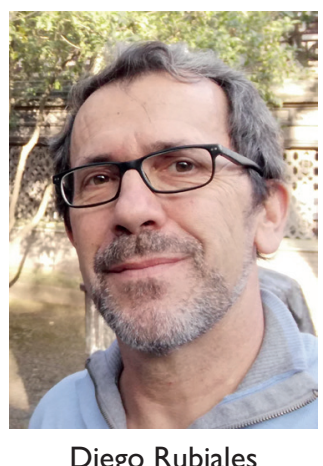

\section{Scope}

The broomrapes are root parasitic weeds, a few of which have adapted to agricultural environments posing serious threats to major crops. In spite of huge efforts in management, rather than being contained, the broomrape threat is increasing, extending to new crops and new areas. Strict phytosanitary controls should therefore be enforced to prevent the inadvertent introduction into non-infected areas and its spread in infected ones.

\section{Introduction}

The broomrapes are plants that have modified their biology to feed on roots of other plants, emerging above the soil only to flower. There are about 150 broomrape species, most of which infect wild plants in natural habitats without causing economic problems. However, a few of them have adapted to agricultural ecosystems becoming troublesome root parasitic weeds. The most damaging ones are Orobanche cernua, O. crenata, O. cumana, O. minor, Phelipanche aegyptiaca and $P$. ramosa all of which severely constrain important dicot crops in Africa, Asia, and Europe. They are continuously extending to new areas, showing an ability to evolve thereby enlarging their host ranges, adapting to new areas and overcoming resistances introduced by the breeder.

As flowering plants disseminated by seeds, broomrape distribution and management (containment, sanitation, cultural practices, and biological and chemical control) fall under the purview of weed science (see reviews by Pérez-deLuque et al. 2010; Fernández-Aparicio et al. 2011a; Goldwasser \& Rodenburg 2013). However, broomrapes differ from standard weeds as they behave as pathogens that attach to host roots to feed on them. As for any other disease, the host plants might protect themselves by defence mechanisms that can be selected by plant breeders to develop resistant cultivars (Rubiales 2018).

In spite of these efforts, rather than being contained, the broomrape threat is increasing, not only extending to new suitable areas (Mohamed et al. 2006; Grenz \& Sauerborn, 2007) but also adapting genetically to infect new crops and to increase virulence (Rubiales 2018).

\section{Geographical expansion}

$P$. ramosa and $O$. crenata have occurred in the Mediterranean Basin for centuries. P. ramosa has historically been widely distributed across the Mediterranean and the whole of Europe infecting hemp grown for fiber, and becoming important on vegetable and tobacco. It has been introduced further north in Europe to Russia, further south in Africa to Ethiopia, and is expanding also to the United States, Mexico, Cuba and Chile in the Americas. O. crenata is widespread in the Mediterranean basin infecting legume crops since antiquity. Actually, $O$. crenata is expanding into southern African areas such as Ethiopia and Sudan (Parker 2012) and northern European areas such as Central Spain (Rubiales et al. 2008) and more recently even to South-Eastern England (Parker 2014).

Contrary to the above mentioned species that cause agricultural problems historically, O. cumana was first reported on sunflower at the end of $19^{\text {th }}$ century in central Russia. It spread all over East Europe in a few decades with the success of the sunflower crop. It is today present in most of the main sunflower-producing countries in Eurasia, from Spain to China (Molinero-Ruiz et al. 2015), being regarded as the most important biotic constraint to sunflower.

Broomrapes are very prolific, producing thousands of tiny seeds that can be dispersed by wind or animals and by movement of contaminated soil or plant debris with farm machinery. Trading of contaminated crop seed lots might be the major cause of introduction into new, previously unoccupied areas and of the spread of new variants. Once introduced, the risk of establishment is strongly affected by mechanisms acting on the seedbank. Relevant processes affecting seed dormancy and viability are driven by the dynamics of soil temperature and moisture, and the presence or absence of hosts. Projecting native-range models of broomrape species to the rest of the world showed that they have great invasive potential, with $O$. cumana and $P$. ramosa posing potential invasive threats to much of the United States, southern and eastern South America, eastern Asia, southern Africa, and southern Australia (Mohamed et al. 2006). O. crenata shows a more restricted invasive potential, still with all Mediterranean climate areas and part of the monsoon, savanna and winterdry climate regions of Central America, Africa, Australia and South Asia all being climatically suitable regions (Grenz \& 


\section{BROOMRAPE THREAT TO AGRICULTURE}

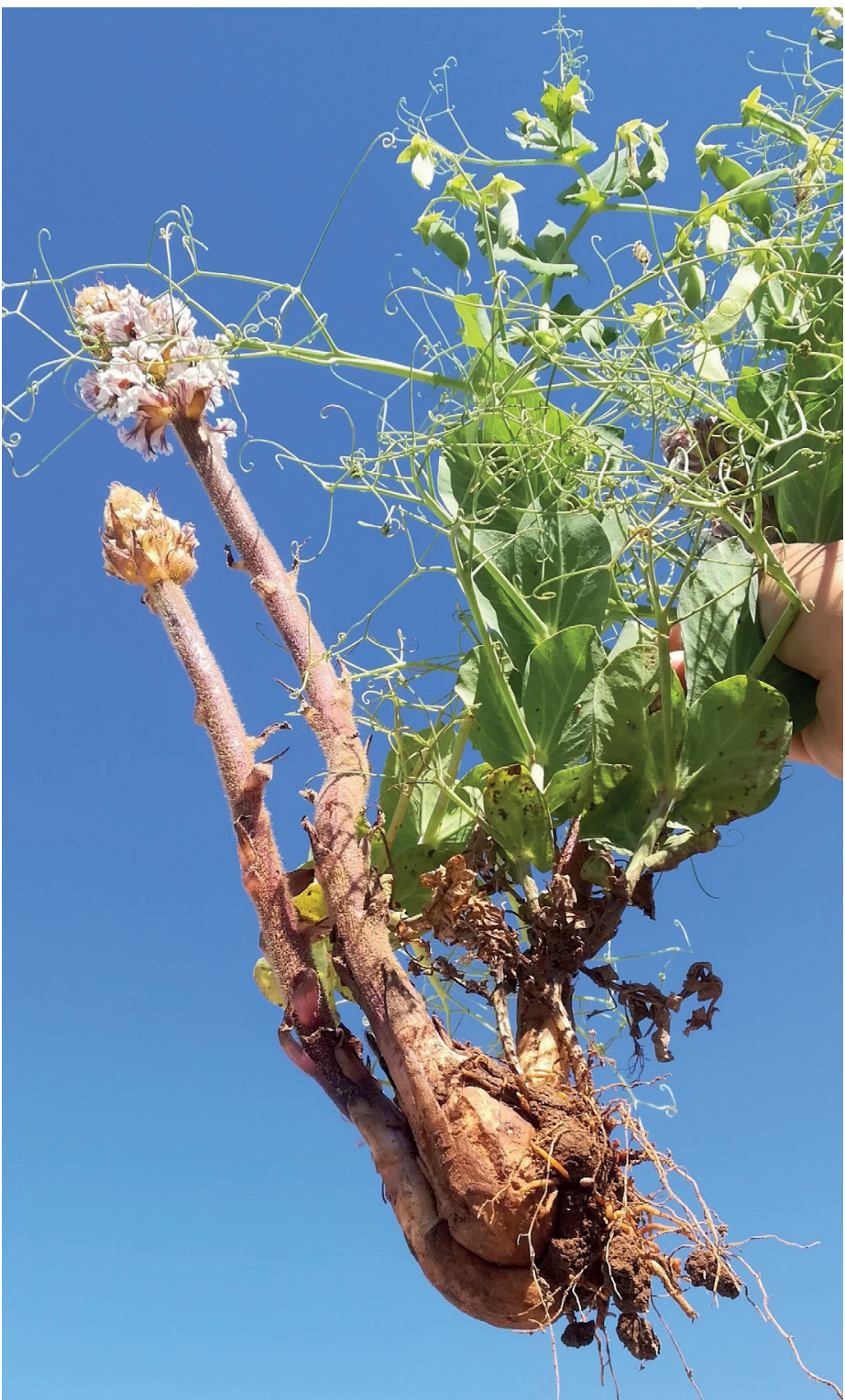

Details of Orobanche crenata infecting pea roots.

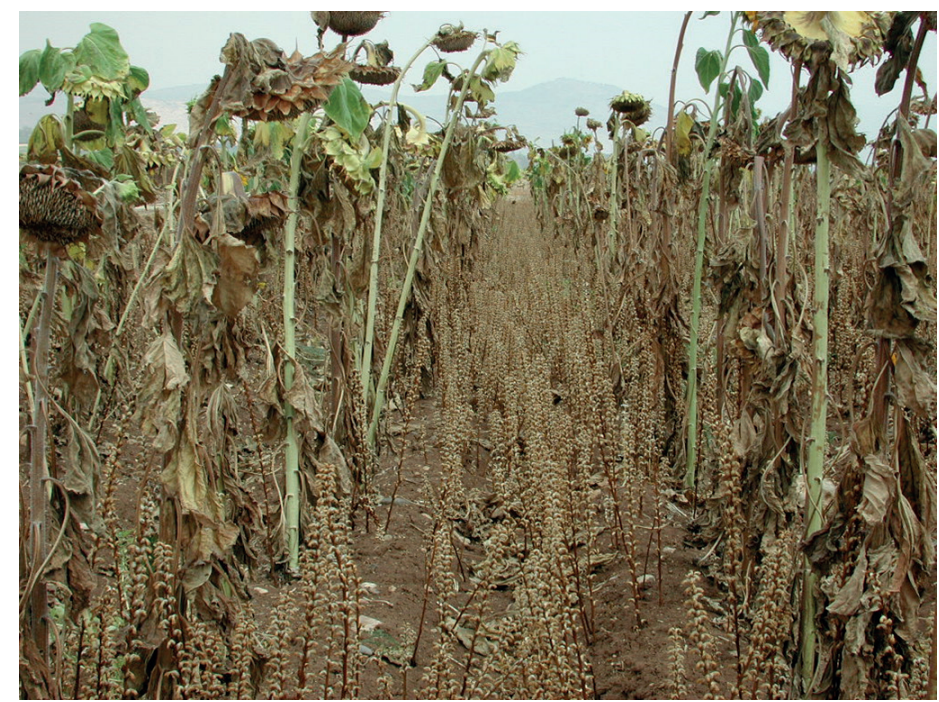

Orobanche cumana infecting sunflower. (Courtesy H. Eizenberg).

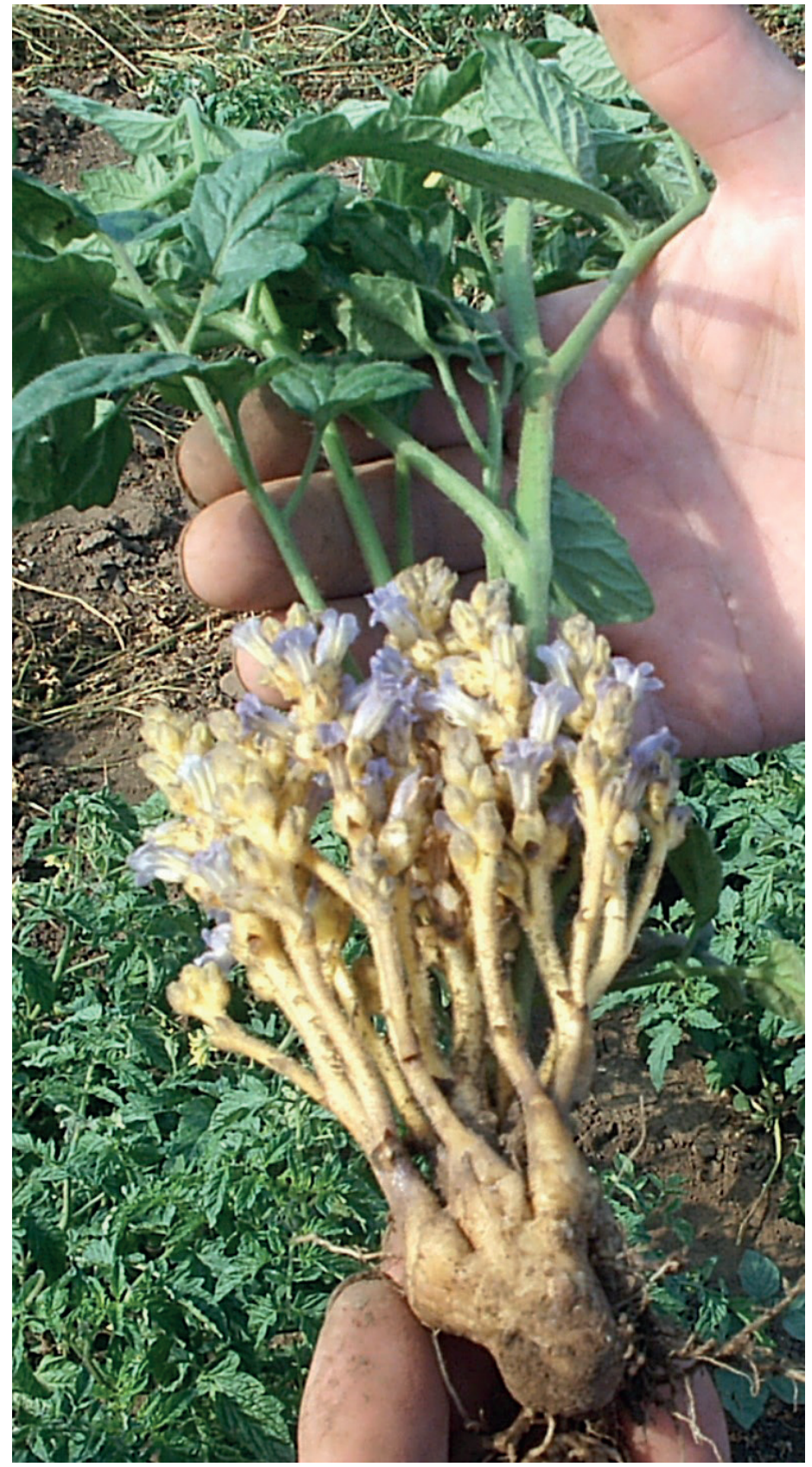

Phelipanche ramosa infecting tomato.

Sauerborn 2007). Such invasive potentials might be enlarged in the future as a result of global change. In addition to this, we cannot exclude the potential of broomrape populations to adapt to new environmental conditions. Strict phytosanitary controls should therefore be enforced to prevent the inadvertent introduction into non-infected areas and its spread in infected areas.

\section{Adaptation from non-weedy to weedy}

$O$. cumana infection on sunflower is an excellent example of adaptation from non-weedy via shift in host range. Nonweedy populations of $O$. cumana are naturally distributed from central Asia to south-eastern Europe parasitizing wild Asteraceae species. Helianthus is a genus native to America, absent from Europe till it was introduced as garden plants in the $16^{\text {th }}$ 
century. Sunflower was developed as a crop as recently as the $19^{\text {th }}$ century in Russia. With the introduction and expansion of sunflower as a new crop, it encountered the non-weedy populations of $O$. cumana that were able to recognize the root exudates of this new crop and to infect it, becoming weedy (Antonova 2014).

Besides $O$. cumana there are other documented instances of jumps from non-weedy to weedy. As an example $O$. foetida is widely distributed in the Western Mediterranean as nonweedy infecting wild legumes only, but evolved a few decades ago to infect legume crops locally, becoming weedy (Vaz Patto et al. 2008). For O. cernua we also have non-weedy populations parasitizing perennial Asteraceae, and weedy populations ascribed to var. desertorum attacking crops like tobacco, tomato, potato, aubergine or pepper, reported to cause significant damage from North and East Africa and the Indian subcontinent.

Co-existing non-weedy populations might represent an additional source of genetic variation for weedy populations by hybridization (Thorogood et al. 2009; Velasco et al. 2016). Hybridization can even occur among close species, such as $O$. cumana and O. cernua, and this might result in changes in host range like the suggested infection of $O$. cumana on tomato in Israel perhaps by introgression with local O. cernua (Joel 2015)

\section{Specialization following host-switching}

Unlike $O$. cumana which is a relatively new problem, $O$. crenata and $P$. ramosa have occurred in the Mediterranean Basin for centuries. There is little genetic variation among their populations, which suggests a long term continuous dispersal of the seeds. Little host-differentiation has been reported for them. P. ramosa is nowadays becoming increasingly important in Central Europe on winter oilseed rape (Gibot-Leclerc et al. 2014), driving to specialization, with new populations adapted to oilseed rape differing in virulence compared with the tomato, hemp or tobacco ones (Stojanova et al. 2019). Host specificity has also been suggested for O. minor (Thorogood et al. 2009), with host driven selection leading to speciation. Only low levels of host specificity have been suggested in O. crenata populations growing on lentil (Ennami et al. 2017).

Specialization following host-switching, is therefore an ongoing process. A first mechanism of host-driven selection is exerted by the recognition system. The seeds of broomrapes germinate only when they detect the chemical signature from roots of an appropriate host, which determines host specificity and thus host range (Fernández-Aparicio et al. 2011b). The best-characterized class of germination stimulants are the strigolactones, but also other metabolites have been reported to contribute to host specificity (see review by Brun et al. 2018). Once the germinated seed contact a host root and a haustorium is differentiated, a battery of mechanisms can prevent root penetration either by reinforcement of cortical host cell walls or at later stages, preventing or retarding further development of broomrape shoots (Pérez-de-Luque et al. 2009; Louarn et al. 2016).

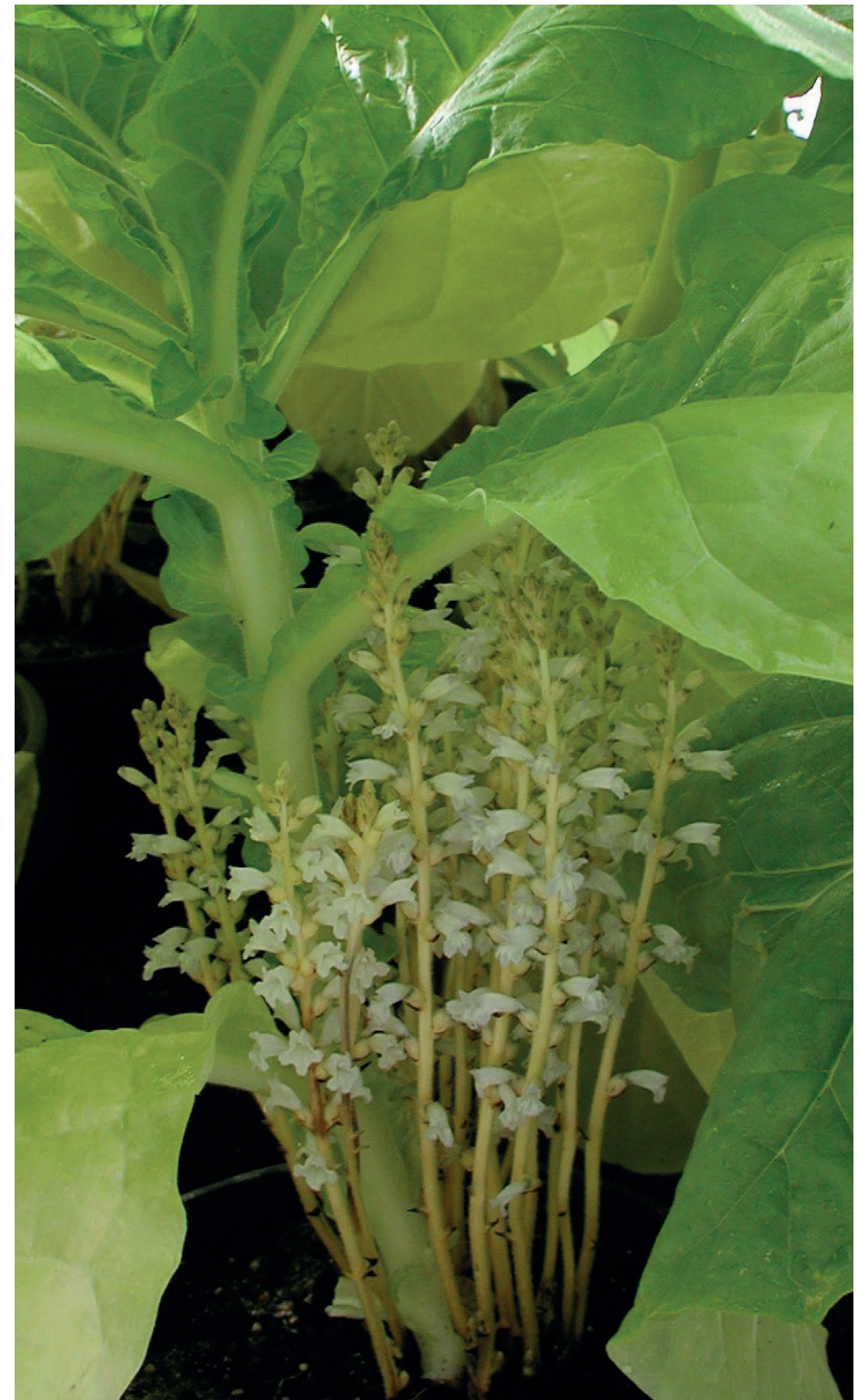

Phelipanche ramosa infecting tobacco.

\section{Increased virulence}

Broomrapes, like microbial plant pathogens, must interact closely with host plants to feed on them and to suppress defense responses, adjusting to the zigzag model for host plant-microbial pathogen interactions in which plants and pathogens are locked in a perpetual 'arms race'. This is best demonstrated in the case of sunflower. O. cumana is so far the only broomrape species in which monogenic resistance was identified in sunflower soon after the onset of the O. cumana problem and was widely exploited in sunflower breeding (Velasco et al. 2016). As a drawback, this wide exploitation over large areas of these highly resistant hybrids imposed high selection pressure on the $O$. cumana populations, leading to the development of races (see Molinero-Ruiz et al. 2015). This continuous emergence and spread of new races of $O$. cumana every $1-2$ decades, from first race A till latest race $\mathrm{H}$, is most worrying and should force a change in the breeding strategy with a recent interest to integrate quantitative resistance and/or combine different resistance mechanisms (Louarn et al. 2016). 
Unlike the sunflower/O. cumana association, little resistance of complex inheritance is so far available against $O$. crenata in legumes, and this forced breeders to accumulate the available quantitative resistances through recurrent breeding. Yet, this resulted in the release of moderately resistant faba bean and pea cultivars (Fondevilla et al. 2017; Rubiales et al. 2018). Probably due to the lack of strong selection pressure on the pathogen, there is no clear evidence for the existence of races in $O$. crenata or in any other broomrape species. More virulent biotypes could be selected when challenged by the widespread use of resistant cultivars, which deserves constant monitoring.

Major efforts are needed to understand broomrape population dynamics better and to design spatial and temporal deployment of resistance genes carefully with the aid of virulence distribution information, which presently is clearly insufficient. Particular efforts are needed on sanitation and quarantine strategies to limit the spread of broomrape seeds into areas still free of infestations, and to prevent expansion of new races.

\section{Acknowledgments}

Broomrape has been my main topic of research over 20 years. It was not an easy task, but I enjoyed learning on it. With this paper I want to thank all my broomrape colleagues and friends for the help and support during this period. Support by Spanish projects AGL2017-82907-R co-financed by FEDER is acknowledged.

\section{References}

Antonova, T.S. 2014. The history of interconnected evolution of Orobanche cumana Wallr. and sunflower in the Russian Federation and Kazakhstan. Helia 37(61), 215-225.

Brun, G., Braem, L., Thoiron, S., Gevaert, K., Goormachting, S., Delavault, P. 2018. Seed germination in parasitic plants: what insights can we expect from strigolactone research?. Journal of Experimental Botany 69, 2265-2280.

Ennami, M., Briache, F.Z., Gaboun, F., Abdelwahd, R., Ghaouti, L., Belqadi, L., Westwood, J., Mentag, R. 2017. Host differentiation and variability of Orobanche crenata populations from legume species in Morocco as revealed by cross-infestation and molecular analysis. Pest Management Science 73, 1753-1763.

Fernández-Aparicio, M., Westwood, J.H., Rubiales, D. 2011a. Agronomic, breeding, and biotechnological approaches to parasitic plant management through manipulation of germination stimulant levels in agricultural soils. Botany 89, 813-826.

Fernández-Aparicio, M., Yoneyama, K., Rubiales, D. 2011 b. The role of strigolactones in host specificity of Orobanche and Phelipanche seed germination. Seed Science Research 21, 55-61.

Fondevilla, S., Flores, F., Emeran, A.A., Kharrat, M., Rubiales, D. 2017. High productivity of dry pea genotypes resistant to crenate broomrape in Mediterranean environments. Agronomy for Sustainable Development 37, 61.

Gibot-Leclerc, S., Reibel, C., Le Corre V., Dessaint, F. 2014. Unexpected fast development of branched broomrape on slowgrowing Brassicaceae. Agronomy for Sustainable Development 35, 151-156.

Goldwasser, Y., Rodenburg, J., 2013. Integrated agronomic management of parasitic weeds seed banks. In: D.M. Joel et al. (eds.), Parasitic Orobanchaceae, Springer-Verlag Berlin Heidelberg, Germany 2013. DOI 10.1007/978-3-642-38146-1_22.
Grenz, J.H., Sauerborn, J. 2007. Mechanisms limiting the geographical range of the parasitic weed Orobanche crenata. Agric. Ecosyst. Environ. 122, 275e281

Joel, D. 2015. Programme and Abstracts, 13th World Congress on Parasitic Plants, Kunming, China, 5-10 July 2015. 20.

Louarn, J., Boniface, M.C., Pouilly, N., Velasco, L., Pérez-Vich, B., Vincourt, P., Muños, S. 2016. Sunflower resistance to broomrape (Orobanche cumana) is controlled by specific QTLs for different parasitism stages. Frontiers in Plant Science 7, 590.

Mohamed, K.I., Papes, M., Williams, R., Benz, B.W., Peterson, T. 2006. Global invasive potential of 10 parasitic witchweeds and related Orobanchaceae. Ambio 35(6), 281-288.

Molinero-Ruiz, L., Delavault, P., Pérez-Vich, B., Pacureanu-Joita, M., Bulos, M., Altieri, E., Domínguez, J. 2015. History of the race structure of Orobanche cumana and the breeding of sunflower for resistance to this parasitic weed: A review. Spanish Journal of Agricultural Research 13, 4, e10R01.

Parker, C. 2012. Parasitic Weeds: A World Challenge. Weed Science 60(2), 269-276.

Parker, C. 2014. Orobanche crenata in UK- an update. Haustorium 65, 5-6.

Pérez-de-Luque, A., Eizenberg, H., Grenz, J.H., Sillero, J.C., Avila, C., Sauerborn, J., Rubiales, D. 2010. Broomrape management in faba bean. Field Crops Research 115, 319-328.

Pérez-de-Luque A., Fondevilla, S., Pérez-Vich, B., Aly, R., Thoiron, S., Simier, P., Castillejo, M.A., Fernández-Martínez, J.M., Jorrín, J., Rubiales, D., Delavault, P. 2009. Understanding Orobanche and Phelipanche - host plant interaction and developing resistance. Weed Research 49, 8-22.

Rubiales, D. 2018. Can we breed for durable resistance to broomrapes?. Phytopathologia Mediterranea 57(1), 170-185.

Rubiales, D., Fernández-Aparicio, M., Rodriguez, M.J. 2008. First report of crenate broomrape (Orobanche crenata) on lentil (Lens culinaris) and common vetch (Vicia sativa) in Salamanca Province, Spain. Plant Disease 92, 1368.

Stojanova, B., Delourme, R., Duffé, P., Delavault, P., Simier, P. 2019. Genetic differentiation and host preference reveal non-exclusive host races in the generalist parasitic weed Phelipanche ramosa. Weed Research 59, 107-118.

Thorogood, C.J., Rumsey, F.J., Harris, S.A., Hiscock, S.J. 2009. Gene flow between alien and native races of the holoparasitic angiosperm Orobanche minor (Orobanchaceae). Plant Systematics and Evolution 282 (1-2), 31-42.

Velasco, L., Pérez-Vich, B., Fernández-Martínez, J.M. 2016 Research on resistance to sunflower broomrape: an integrated vision. OCL, DOI: $10.1051 / \mathrm{ocl} / 2016002$.

Vaz Patto, M.C., Díaz-Ruiz, R., Satovic, Z., Román, B., PujadasSalvà, A.J., Rubiales, D. 2008. Genetic diversity of Moroccan populations of Orobanche foetida: evolving from parasitising wild hosts to crop plants. Weed Research 28, 179-186.

Diego Rubiales is Professor and leader of the Stress Resistance Group at the Institute for Sustainable Agriculture, CSIC, Córdoba, Spain. His research interest is resistance to diseases in cereals and legumes. He was awarded a PhD in Plant Breeding at the University of Cordoba in 1991 and then was postdoc in Holland. In 1993 got a permanent position as scientist at CSIC at Cordoba, as senior scientist and then as Professor.

During the first 10 years of his career he worked on resistance to fungal diseases in cereals and then slowly moved to legumes. Although his background was on resistance to fungal diseases, when trying to contribute to solving legume problems in a Mediterranean country he faced the Orobanche crenata problem. Resistance to broomrape became then a central part of his research in the past 20 years. This was not an easy task. Everything started with 
coordination of COST action 849 "Parasitic Plant Management in Sustainable Agriculture" that allowed proper contacts and collaborations. Since then he has been quite successful in coordinating a substantial number of national and international projects on resistance to diseases on legumes. Unfortunately, in spite of his wishes, broomrape was not the major target of any of those funded projects. Fortunately, thanks to a lot of motivation and enthusiasm he managed to maintain some continuity on broomrape research. This was possible only thanks to huge efforts, a lot of luck and excellent collaborations.

As a result, he published $>300$ articles in major journals, $>90$ of which are on parasitic weeds, besides a substantial number of book chapters, dissemination articles and congress presentations, compiling $h=43$. He has been President of the International Legume Society (20II-2016) and of the European Associa- tion of Grain Legumes Research (2008-2012). Has also served in the Executive Committee of the Int. Parasitic Plant Society, and was awarded Honorary Membership in 2015. However, what he feels most proud is on the number of excellent students that were trained ( $27 \mathrm{PhDs}, 8$ of whom were on resistance to broomrape) and particularly, the registration of the first pea cultivars resistant to broomrape.

For details:

https://www.researchgate.net/profile/Diego_Rubiales https://www.ias.csic.es/en/plant-breeding/breeding-resistancebiotic-abiotic-stresses/diego-rubiales-olmedo/ 